[Bull. Agr. Chem. Soc. Japan, Vol. 23, No. 1, p. 1 3, 1959]

\title{
Attempted Syntheses of Tetracyclin Analogues. Part I.
}

\author{
By Masanao Matsur and Yoshihiko Nishizawa* \\ Faculty of Agriculture, University of Tokyo \\ Received April 5, 1956
}

\begin{abstract}
Diethyl- $\alpha$-benzyl- $\alpha$-(3-(3-methylphthalidyl))-malonate and diethyl- $\alpha$-benzoyl- $\alpha$-(3-(3-methylphthalidyl))-succinate as intermediates of aureomycinic acid analogues, and 2, 10-dibromo-1.4dioxo-1 4.5.8.9.10-hexahydronaphthalene as intermediate of tetracyclin $\mathrm{A}$. $\mathrm{B}$ ring analogue have been prepared.
\end{abstract}

The structure which is common to both terramycin and aureomycin have been named tetracyclin by C. R. Stephens et al."

We attempted to prepare the analogues of this tetracyclin and in the course a few products as the intermediates of these analogues were synthesized.

Namely, with a view of synthesizing the an- alogues of aureomycinic acid ${ }^{2)}$ which had been isolated as degradation product of aureomycin, the coupling reaction was first tried between 3-chloro-3-methylphthalide (acetophenon-o-carboxylic acid pseudo-acid chloride) (II) and diethyl benzoyl sodio malonate (III) and diethyl- $\alpha$-benzyl- $\alpha$-(3-(3-methylphthalidyl))-malonate (IV) was yielded.<smiles>CN(C)C1C(O)=C(C(N)=O)C(O)C(O)C1CC(CC(=O)O)C12CC3(C)C(C(=O)O1)C(O)CCC(Cl)C32C</smiles>

(I)

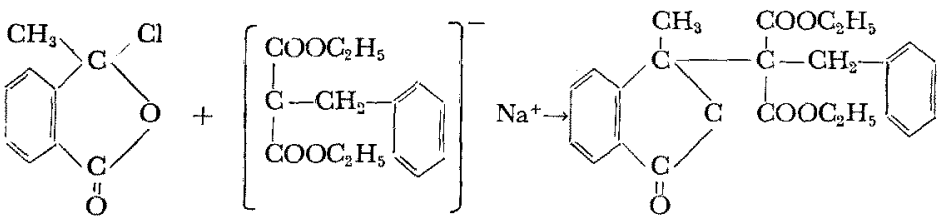

(II)

(III)<smiles>CCOC(=O)CC(CC(=O)OCC)C(=O)Oc1cccc([I-])c1</smiles>

(V)<smiles>CCOC(=O)CC(CC(=O)OCC)(C(=O)OCC)C1(C)OC(=O)c2cc([N+]#N)ccc21</smiles>

(VI) 
This pseudo-acid chloride (II) was highly anstable and decomposed at $45^{\circ} \mathrm{C}$.

Reaction between the pseudo-acid chloride and diethyl benzoyl sodio succinate $(\mathrm{V})$ yielded diethyl - $\alpha$ - benzoyl - $\alpha$ - (3-(3-methylphthalidyl))succinate (VI).

Diethyl- $\alpha$-benzoyl- $\alpha$-(3-(3-methylphthalidyl))malonate, however, was found to be quite stable to acid hydrolysis, and after twelve hours reflux in concentrated hydrochloric acid the two ester groups still retained.

Since these compounds (IV) and (VI) have two asymmetric centers, it exists in two racemic forms or diasteres isomers, but we could not isolate them because the sample was very small in quantity.

As the first attempt to prepare a tetracyclin A. B ring analogue, we tried to use Diels-Alder reaction between butadien and some benzoquinone derivatives.

The reaction between 2,5-dimethoxy-benzoquinone and butadien did not proceed as expected and could not be obtained at all. But when 2,5-dibromo-benzoquinone (VII) and butadien had been heated in benzene at $100^{\circ} \mathrm{C}$ in sealed tube for six hours, a light yellow adduct (VIII) $)^{3)}$ was obtained in good yicld.

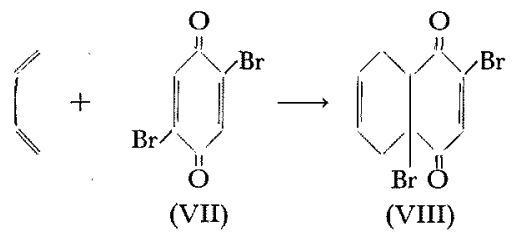

This adducts (VIII) was somewhat unstable, discoloured after a long time at room temperature, and festered skin, the solution of this adduct in benzene was specially hard and proved toxic to house flies.

One bromine-atom of this adduct was very unstable, therefore the authors could not prepared 2,9-diacetoxy-1.4-dioxo-1.4.5.8.9.10-hexahydronaphthalen from this adduct with silver acetate.

As the studies are now in progress, they will

3) Matsui and Nishizawa, Jap. pat. No. 227,481. be published in future.

\section{EXPERIMENTAL}

\section{3-Chloro-3-methylph thalide (II)}

A mixture of $8.2 \mathrm{~g}$ of acetophenon-o-carboxylic acid 43 and $10.4 \mathrm{~g}$ of phosphorus pentachloride were stirred in $30 \mathrm{ml}$. of dry benzene for two hours below $40^{\circ} \mathrm{C}$. The clear solution was filtered and the filtrate was evaporated in vacuo at room temperature and petroleum ether $(50 \mathrm{ml}$.) was added. After cooling for one day the solid was filtered and washed with petroleum ether; yield $8.0 \mathrm{~g}$. This product was not further purified but was used for the further reactions.

Diethyl- $a \cdot$-henzyl- $\alpha-(3 \cdot(3-m e t h y l p h t h a l i d y l))-$ malonate (V)

To a stirred dry benzene solution suspended with $0.9 \mathrm{~g}$ of sodium-sand was added $10 \mathrm{~g}$ of diethyl- $\alpha$-benzylmalonated ${ }^{57}$ dissolved in the equal quantity of dry benzene. The mixture was refluxed for four hours.

After the sodium-sand was dissolved completely a suspension of $3 \mathrm{~g}$ of 3-chloro-3-methylphthalide in 20 $\mathrm{ml}$. of dry benzene was added to the solution at room temperature.

Stirring was continued for one hour at room temperature then the mixture was refluxed until it became neutral, cooled, and the insolubles were removed by filteration. The clear benzene solution was concentrated to dryness in vacuo and the dark red residual oil was diluted with alcohol.

The crystalline product was filtered and dried, wt. 4.0 g,m.p. $141-143^{\circ}$. A portion of it was crystallized twice from acetic acid; m.p. $145-146^{\circ}$. Anal. Calcd. for $\mathrm{C}_{23} \mathrm{H}_{24} \mathrm{O}_{6} ; \mathrm{C}, 69.68 ; \mathrm{H}, 6.10$

Found: C, 69.33; H, 6.25

\section{Diethyl- $\alpha$-benzoyl- $\alpha$-(3-(3-methylphthalidyl))-} succinate (VI)

This was prepared using $0.5 \mathrm{~g}$ of sodium-sand, $6.1 \mathrm{~g}$ of $\alpha$-benzoyl-succinate ${ }^{6)}$ and $4.1 \mathrm{~g}$ of 3-chloro-3-methylphthalide by the above discribed methods.

The crystalline product was $3.2 \mathrm{~g}, \mathrm{~m}$.p. $220-221^{\circ} \mathrm{C}$. Anal. Calcd. for $\mathrm{C}_{23} \mathrm{H}_{24} \mathrm{O}_{7} ; \mathrm{C}, 67.91 ; \mathrm{H}, 5.70$

Found: $\mathrm{C}, 67.88 ; \mathrm{H}, 5.76$

\subsection{0-Dibromo-1.4-dioxo-1.4.5.8.9.10-hexahydro- naphthalene (VIII)}

Five and four tenth grams of 2.5-dibromo-p-benzoquinone $^{7)}$ (m.p. $188^{\circ}$ ), $1.6 \mathrm{~g}$ of freshly distilled buta-

\footnotetext{
4) Gabriel, Ber., 10, 1553.

5) Leuchs, Ber.: 44, 1509.

6) Perkin, J. An. Chem. Soc, 47, 273 (1925).

7) Sacauw, Ann., 209, 112 (1881).
} 
dien; $40 \mathrm{ml}$. of benzene were shaken in seald tube at $100^{\circ} \mathrm{C}$ for six hours. The light-yellow reaction mixture was filtered, and concentrated to dryness in vacuo.

The crude product was recrystallized from alcohol;
5.3 g,m.p. 94-95 Anal. Calcd. for $\mathrm{C}_{10} \mathrm{H}_{8} \mathrm{O}_{2} \mathrm{Br}_{2} ; \mathrm{C}$, $37.50 ; \mathrm{H}, 2.5$

Found: $\mathrm{C}, 37.38 ; \mathrm{H}, 2.31$

[Bull. Agr. Chem. Soc. Japan, Vol. 23, No. 1, p. 3 6, 1959]

\title{
The Effect of Riboflavin on. Hypertension induced by High Salt Diet in the Rat
}

\author{
By Tatsuo Koyanagi, Shin'ichi Hareyama and Minoru Ota \\ Department of Agricultural Chemistry, Faculty of Agriculture, Twate University
}

Received November 19, 1956

\begin{abstract}
The effect of riboflavin on development of hypertension in rats given a high salt diet was studied. Large doses of riboflavin prevented both elevation of blood pressure and rise of cholesterol levels in the serum. The increase in liver monoamine oxidase activity of the rats fed riboflavin was confirmed.
\end{abstract}

Calder ${ }^{1)}$ reported that rats fed a vitamin B-deficient diet showed a higher level of blood pressure than those fed a similar diet supplemented with yeast or liver extracts and considered that the vitamin B group contained in the supplements may inhibit the elevation of blood pressure of the animals. The present study was designed to determine whether riboflavin is effective to inhibit the elevation of blood pressure in rats induced by a saltrich diet.

\section{EXPERIMENTAL AND RESULTS}

The first experiment; A preliminary examination was performed to find the effect of ribotlavin on salthypertension occurring in animals. In this study, ten two-month-old Wister strain albino rats were divided into two groups; one of them was fed a basal diet

1) R.M. Calder, J. Exp. Med., 76, 1 (1942); 79, 215 (1944). consisting of $91.8 \mathrm{~g}$ polished rice, $5 \mathrm{~g}$ casein, $0.5 \mathrm{~g}$ calcium carbonate, $2.5 \mathrm{~g}$ sodium chloride, $0.2 \mathrm{~g}$ dried carrot powder and $0.1 \mathrm{mg}$ thiaminehydrochloride, the other was fed a basal diet plus $1 \mathrm{mg}$ riboflavin. The basal diet contained $0.071 \mathrm{mg}$ riboflavin. The diet which was pasted by heating with $100 \mathrm{ml}$ water per $100 \mathrm{~g}$ was given ad. lib. and drinking water was restricted according to the suggestion of Sapirstein ${ }^{2)}$ that the ratio of sodium chloride to water intake, rather than the amount of sodium chloride, is considered to be the determining factor for development of this type of hypertension.

After three months' feeding, systolic blood pressure of the rat was measured by the method of Williams et al. ${ }^{32}$ and then, the animals were sacrificed by decapitation and their liver and kidney removed immediately so as to serve for the determinations of

2) L. A. Sapirstein, W. L. Brandt, and D. R. Drury, Proc. Soc Exp. Biol. Med.. 73, 82 (1950).

3) J.R. Williams, 'T. R. Hatison and A. Goliman, J. Clin. Invest., 18, 373 (1939). 